\title{
ПОШИРЕНІСТЬ КОМОРБІДНОЇ ПАТОЛОГІЇ У ВІЙСЬКОВОСЛУЖБОВЦІВ, ХВОРИХ НА ІШЕМІЧНУ ХВОРОБУ СЕРЦЯ
}

\author{
Т.В. Куц, Г.З. Мороз
}

Українська військово-медична академія, м. Київ, Украӥна

\begin{abstract}
Мета - визначити поширеність коморбідної патології у військовослужбовців, хворих на ішемічну хворобу серця (IXC), які проходили лікування в кардіологічному відділенні Національного військовомедичного клінічного центру «Головний військовий клінічний госпіталь» (НВМКЦ «ГВКГ»).

Матеріали і методи. Проведено аналіз 100 історій хвороби випадкової вибірки пацієнтів кардіологічного відділення, які були госпіталізовані в НВМКЦ «ГВКГ» в 2020 році з діагнозом IХС. Всі хворі були чоловічої статі, віком від 40 до 60 років. Для дослідження вікових особливостей поширеності коморбідної патології хворі на ІХС були розділені на дві групи: 40-50 років (1 група - 45 пацієнтів) та 5160 років (II група - 55 пацієнтів). Статистична обробка проводилась з використанням програми Місгоsоft Exсеl 2007 та стандартного статистичного пакета STATISTICA 6,0.

Результати. Визначено значну поширеність коморбідних захворювань у хворих на ІХС: кількість супутніх захворювань була від 2 до 10. Артеріальна гіпертензія була виявлена у 100\% хворих I та II групи. Серед інших коморбідних серцево-судинних захворювань: цереброваскулярні захворювання були

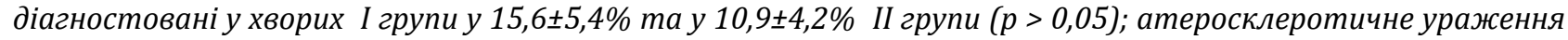

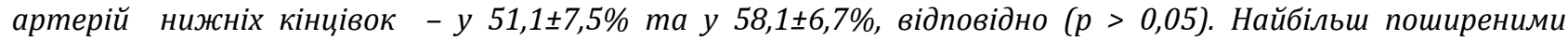
коморбідними захворюваннями системи органів травлення були: хронічний холещистит (у 26,7士6,6\% хворих

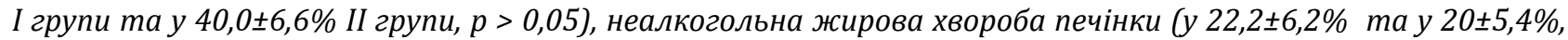

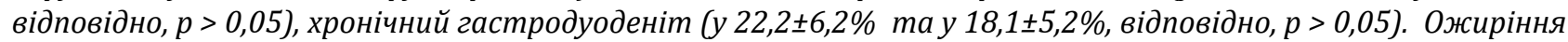

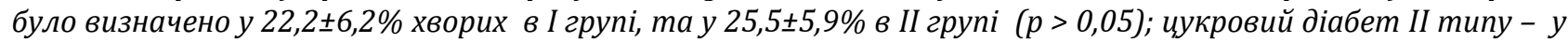

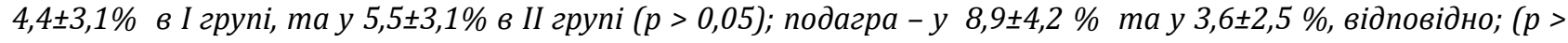

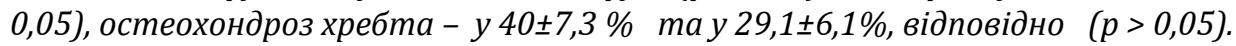

Висновки. Результати проведеного дослідження засвідчили значне поширення коморбідної патології у хворих на IXС, які проходили лікування в НВМКЦ «ГВКГ», що має важливе значення для прогнозу та призначення лікування. Найбільш поширеними були артеріальна гіпертензія (100\%),

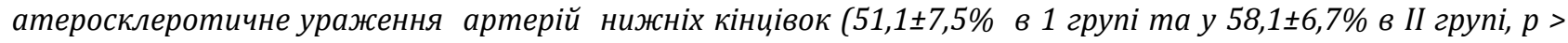

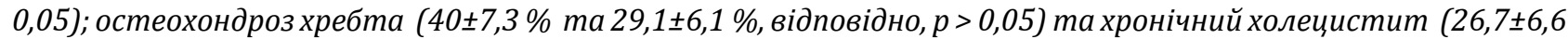

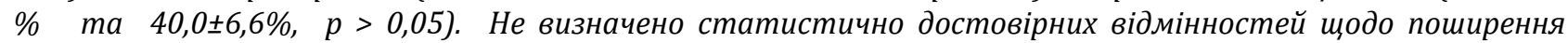
коморбідної патології у хворих на ІХС у віковій групі 40-50 років та 51-60 років.
\end{abstract}

Ключові слова: ішемічна хвороба серця, військовослужбовці, коморбідність

Вступ. Україна належить до країн 3 високим рівнем поширеності серцевосудинних захворювань. В період з 2000 р. по 2016 р. поширеність серцево-судинних захворювань збільшилася на 45,0%, зокрема, поширеність артеріальної гіпертензії - на $58,3 \%$, ішемічної хвороби серця (IXC) - на $53,0 \%$, цереброваскулярних хвороб - на 16,8\% [1]. Серцево-судинні захворювання займають перше місце у структурі первинної інвалідності та смертності дорослого населення. Протягом 1991-2015 рр. показник смертності від серцево-судинних захворювань в Україні зріс вдвічі та є одним із найвищих у Європі [1].

Актуальною ця проблема $\epsilon$ i для Збройних Сил (3С) України. Воєнно-медичною доктриною України, яка була затверджена в 2018 році, визначено шляхи формування та впровадження єдиних підходів до збереження i зміцнення здоров'я військовослужбовців, надання медичної допомоги [2]. Впродовж багатьох років хвороби системи кровообігу посідають провідні позиції в структурі захворюваності, працевтрат, смертності та звільнень за медичними показами військовослужбовців ЗС України [3]. Особливе місце займає IXC, враховуючи їі поширеність i роль в розвитку серцево-судинних ускладнень. Все це обумовлює необхідність підвищення якості медичної допомоги військовослужбовцям, хворим на IXC. Сучасний розвиток медицини характеризується постійним оновленням Клінічних рекомендацій, з урахуванням нових підходів, які грунтуються на засадах доказової медицини. В 2019 році затверджені Рекомендації ESC 3 діагностики та ведення пацієнтів 3 хронічними коронарними синдромами [4], в яких наголошується на необхідності комплексної оцінки перебігу IXC, 3 урахуванням коморбідних станів та 
захворювань. Тому важливо, провести аналіз поширеності коморбідної патології у військовослужбовців, хворих на IXC на сучасному етапі.

Мета дослідження - визначити поширеність коморбідної патології у військовослужбовців, хворих на IXC, які проходили лікування в кардіологічному відділенні Національного військовомедичного клінічного центру «Головний військовий клінічний госпіталь» (НВМКЦ «ВКГ»).

Матеріали та методи дослідження. Проведено аналіз 100 історій хвороби випадкової вибірки пацієнтів кардіологічного відділення, які були госпіталізовані в НВМКЦ «ГВКГ» в 2020 році з діагнозом IXC. Всі хворі були чоловічої статі, віком від 40 до 60 років. Для дослідження вікових особливостей поширеності коморбідної патології хворі на IXC були розділені на дві групи: 40-50 років (1 група - 45 пацієнтів) та 51-60 років (II група 55 пацієнтів). Середній вік обстежених I групи

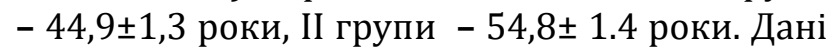
3 історії хвороби вносились в комп'ютерну базу даних.

Дослідження виконали на підставі інформованої згоди щодо участі в обстеженні відповідно до Гельсінської декларації. Дизайн дослідження узгоджено з комісією з біоетики Української військово-медичної академії.

Статистична обробка проводилась 3 використанням програми Microsoft Excel 2007 та стандартного статистичного пакета STATISTICA 6,0.

Для кількісних показників первинна статистична обробка включала у себе розрахунок середнього арифметичного (M) та стандартної помилки (m). Для змінних найменувань та рангових змінних первинна обробка включала в себе розрахунок відсотків (P). Відмінності між вибірками, оцінювались за параметричним критерієм Ст'юдента (t). Достовірність відмінностей оцінювалась за рівнем значимості р. Критичний рівень значимості при перевірці статистичних гіпотез у даному дослідженні приймали рівним 0,05.

Результати дослідження та їх обговорення. За матеріалами історій хвороби проведено аналіз поширеності коморбідних захворювань і станів у пацієнтів I та II групи. Результати проведеного дослідження засвідчили значну поширеність коморбідних серцево-судинних захворювань у хворих на
IXC. Артеріальна гіпертензія була діагностована у 100\% хворих I та II групи, що потребує уваги i моніторингу досягнення цільового рівня артеріального тиску. Клінічними дослідженнями доведено, що артеріальна гіпертензія $€$ провідним чинником, який має негативний вплив на смертність від серцево-судинних захворювань [4]. Атеросклеротичне ураження судин різної локалізації також підвищує ризик розвитку ускладнень у хворих на IXC [4]. За результатами нашого дослідження цереброваскулярні захворювання були

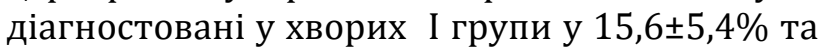
y $10,9 \pm 4,2 \%$ II групи (p > 0,05). Атеросклеротичне ураження артерій нижніх кінцівок було діагностовано у хворих I групи у $51,1 \pm 7,5 \%$ та у $58,1 \pm 6,7 \%$ II групи (p > 0,05). Фактори ризику атеросклеротичного ураження артерій нижніх кінцівок типові для атеросклерозу, проте доведено, що у таких пацієнтів куріння $\epsilon$ важливим чинником ризику. Цей аспект проблеми є важливим для військовослужбовців, враховуючи значну поширеність тютюнокуріння [5]. Тому визначена нами висока частота атеросклеротичного ураження артерій нижніх кінцівок у хворих на IXC потребує комплексного підходу щодо лікування.

Захворювання органів травлення серед військовослужбовців посідають одне 3 провідних місць в структурі терапевтичної патології в Україні на сучасному етапі [6]. Крім цього, на сьогоднішній день для захворювань шлунково-кишкового тракту характерною рисою $є$ множинність супутніх захворювань, які можуть взаємно впливати на перебіг i клінічні прояви. Коморбідність серцевосудинних захворювань і захворювань системи органів травлення необхідно враховувати при призначенні лікування і профілактиці ускладнень. Результати проведеного нами дослідження засвідчили значну поширеність хронічного холециститу, неалкогольної жирова хвороба печінки, хронічного гастродуоденіту, виразкової хвороби шлунка та дванадцятипалої кишки i гастроезофагальної рефлюксної хвороби у хворих на IXC (табл. 1).

Хронічний холецистит, за результатами

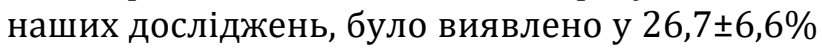
хворих I групи та у 40,0土6,6\% II групи, що в цілому відповідає даним інших досліджень щодо обстеження хворих на IXC [7]. 
Таблиця 1

Частота виявлення коморбідних захворювань системи органів травлення у хворих на IXC, \%

\begin{tabular}{|l|c|c|c|}
\hline $\begin{array}{l}\text { Коморбідні захворювання системи органів } \\
\text { травлення }\end{array}$ & $\begin{array}{c}\text { I група } \\
\text { (n=45) } \\
\mathrm{P} \pm \mathrm{m}\end{array}$ & $\begin{array}{c}\text { I I група } \\
\text { (n=55) } \\
\mathrm{P} \pm \mathrm{m}\end{array}$ & $\begin{array}{c}\mathrm{p} \\
\text { I-II група }\end{array}$ \\
\hline $\begin{array}{l}\text { Виразкова хвороба шлунка/ } \\
\text { дванадцятипалої кишки }\end{array}$ & $6,7 \pm 3,7$ & $9,1 \pm 3,9$ & 0,66 \\
\hline Хронічний гастродуоденіт & $22,2 \pm 6,2$ & $18,1 \pm 5,2$ & 0,62 \\
\hline $\begin{array}{l}\text { Гастроезофагальна } \\
\text { рефлюксна хвороба }\end{array}$ & $15,5 \pm 5,4$ & $3,6 \pm 2,5$ & 0,05 \\
\hline Хронічний холецистит & $26,7 \pm 6,6$ & $40,0 \pm 6,6$ & 0,16 \\
\hline Неалкогольна жирова хвороба печінки & $22,2 \pm 6,2$ & $20,0 \pm 5,4$ & 0,8 \\
\hline
\end{tabular}

Неалкогольна жирова хвороба печінки поширене хронічне захворювання печінки, яке виявляють у популяціях різних країн у 10-24\% випадків і яке не залежить від віку та расової належності [8].

За результатами наших досліджень неалкогольну жирову хворобу печінки було виявлено у $22,2 \pm 6,2 \%$ хворих I групи та у $20 \pm 5,4 \%$ II групи (p > 0,05). Необхідно враховувати, що неалкогольна жирова хвороба печінки патогенетично пов'язана 3 цукровим діабетом та ожирінням, які мають значимий вплив на прогноз у хворих на IXC. За результатами наших досліджень цукровий діабет II типу було діагностовано у $4,4 \pm 3,1 \%$ в I групі, та у $5,5 \pm 3,1 \%$ в II групі (p > 0,05). Такі пацієнти потребують особливої уваги, тому що у хворих на діабет та IXC характерні атипові прояви ангінозного болю (довший, атипової локалізації або, навпаки, відсутній); часте поєднання 3 порушеннями ритму та провідності; часте ураження декількох коронарних артерій, що призводить до інфаркту, який має ускладнений перебіг [9].

Ожиріння $\epsilon$ чинником, який значно збільшує ризик порушення ліпідного обміну, що в свою чергу має негативний вплив на перебіг IXC. За результатами наших досліджень ожиріння було визначено у $22,2 \pm 6,2 \%$ хворих в I групі, та у $25,5 \pm 5,9 \%$ в II групі $(\mathrm{p}>0,05)$.

Серед коморбідних станів при серцевосудинних захворюваннях останнім часом особлива увага вчених сфокусована на проблемі гіперурикемії та подагри, які призводять до підвищення кардіоваскулярного ризику [4]. Саме тому своєчасне встановлення діагнозу подагри, раннє і раціональне призначення лікування має безпосереднє клінічне і соціальне значення. Результати проведеного нами дослідження засвідчили, що подагра була діагностована у $8,9 \pm 4,2 \%$ хворих на IXC I групи та у $3,6 \pm 2,5 \%$ II групи ( $>$ > 0,05).

Поширеним коморбідним станом у хворих на IXC $\epsilon$ остеохондроз, який за результатами наших досліджень, було виявлено у $40 \pm 7,3 \%$ хворих у I групі та у $29,1 \pm 6,1 \%$ в II групі (p > 0,05). Отримані результати щодо поширеності остеохондрозу в цілому відповідають даним інших досліджень [7].

Таким чином, результати проведеного дослідження засвідчили значне поширення коморбідної патології у хворих на IXC, які проходили лікування в НВМКЦ «ГВКГ». Наше дослідження демонструє, що кількість супутніх захворювань у хворих на IXC була від 2 до 10, як в I групі, так і в II групі. Не визначено статично достовірних відмінностей щодо поширення коморбідної патології у хворих на IXC різних вікових груп. Опубліковані у 2016 році результати дослідження, проведеного у Словенії, показали негативний вплив на загальний стан здоров'я та показник якості життя пацієнтів 3 IXC хронічної серцевої недостатності, атеросклеротичного ураження периферичних артерій, наявності тривоги та/або депресії [10]. 3 іншого боку, збільшення кількості коморбідних захворювань потребує зваженого підходу щодо призначення фармакотерапії та попередження поліпрагмазії. Для сучасної медичної практики важливою $є$ проблема лікування не одиничної нозології, а конкретного хворого з урахуванням усіх можливих факторів ризику та коморбідності [11]. Цей аспект потребує проведення подальших досліджень і розробки нової моделі допомоги.

\section{Висновки}

1. Результати проведеного дослідження засвідчили значне поширення коморбідної патології у хворих на IXC, які проходили 
лікування в НВМКЦ «ГВКГ», що має важливе значення для прогнозу та призначення лікування. Кількість супутніх захворювань у хворих на IXC була від 2 до 10.

2. Встановлено, що найбільш поширеними коморбідними захворюваннями у військовослужбовців, хворих на IXC, були артеріальна гіпертензія (100\%), атеросклеротичне ураження артерій нижніх кінцівок

\section{Література}

1. Моніторинг проблем, пов'язаних 3 неінфекційними захворюваннями, як основа профілактичних стратегій та програм дій / Грузєва T. С. та ін. Щорічна доповідь про стан здоров'я населення, санітарно-епідемічну ситуацію та результати діяльності систем охорони здоров'я України. 2016 рік : доповідь [для керівників і спеціалістів органів законодавчої та виконавчої влади усіх рівнів, організаторів охорони здоров'я, науковців, лікарів, громадськості] / Укр. ін-т стратег. дослідж. М03 України ; ред. П. С. Мельник [та ін.]. - Київ : Коломіцин В.Ю., 2017. - 516 с (492-502).

2. Постанова Кабінету Міністрів України від 31 жовтня 2018 р. № 910 «Про затвердження Воєнномедичної доктрини України» URL: https://zakon.rada.gov.ua/laws/show/910-2018-п

3. Ткачук I. М. Хвороби системи кровообігу у військовослужбовців Збройних Сил України: вплив на придатність до військової служби. Вісник соціальної гігієни та організації охорони здоров'я України. 2017. № 4. С. 18-22. URL: http://nbuv.gov.ua/UJRN/VSG_2017_4_5.

4. 2019 ESC Guidelines for the diagnosis and management of chronic coronary syndromes: The Task Force for the diagnosis and management of chronic coronary syndromes of the European Society of Cardiology (ESC) / J. Knuuti et al. Eur Heart J. 2020. V 41(3), $P$. 407-477. https://doi.org/10.1093/eurheartj/ehz425.

5. Тютюнокуріння у військовослужбовців: сучасний стан проблеми та готовність до зміни

\section{References}

1. Hruzieva, T.S., Haliienko, L.I., Ziukov, O.L., Zamkevych, V.B., Inshakova, H.V., Soroka, I.M., Ionov, M.M. (2017) Monitorynh problem, poviazanykh $\mathrm{Z}$ neinfektsiinymy zakhvoriuvanniamy, yak osnova profilaktychnykh stratehii ta prohram dii: Shchorichna dopovid pro stan zdorovia naselennia, sanitarnoepidemichnu sytuatsiiu ta rezultaty diialnosti systemy okhorony zdorovia Ukrainy. 2016 rik, Kyiv, 492-502.

2. Pro zatverdzhennia Voienno-medychnoi doktryny Ukrainy. Postanova Kabinetu Ministriv Ukrainy vid 31 zhovtnia 2018 r. № 910 (2018). URL: https://zakon.rada.gov.ua/laws/show/910-2018-ח.

3. Tkachuk, I. M. (2017) Khvoroby systemy krovoobihu u viiskovosluzhbovtsiv Zbroinykh Syl Ukrainy: vplyv na prydatnist do viiskovoi sluzhby. Bulletin of social hygiene and health care organization of Ukraine, 4, 18-22. https://doi.org/10.11603/1681$\underline{2786.2017 .4 .8648}$
$(51,1 \pm 7,5 \%$ в I групі та у $58,1 \pm 6,7 \%$ в II групі, p $>0,05)$; остеохондроз хребта $(40 \pm 7,3 \%$ та $29,1 \pm 6,1 \%$, відповідно, р > 0,05) та хронічний холецистит $(26,7 \pm 6,6 \%$ та $40,0 \pm 6,6 \%, p>0,05)$. 3. Не визначено статистично достовірних відмінностей щодо поширення коморбідної патології у хворих на IXC у віковій групі 40-50 років та 51-60 років.

нездорової поведінки / Мороз Г. З. та ін. Військова медицина України. 2018. Т. 18. № 1. С. 71-76.

6. Терапевтичні аспекти війни на Сході України: монографія / М.П.Бойчак, Г.В. Осьодло. К.: Людмила, 2020. $320 \mathrm{c}$.

7. Comorbidity in patients with chronic coronary syndromes: prevalence and assessment / Galina Z. Moroz et al. Wiadomości Lekarskie. 2020. Tom LXXIII, $\begin{array}{llll}\mathrm{Nr} & 3 . & \text { S. } & 462-465 .\end{array}$ https://doi.org/10.36740/WLek202003110

8. Ткач С.М., Чеверда Т.Л. Неал https://doi.org/когольна жирова хвороба печінки: поширеність, природний перебіг, сучасні підходи до діагностики та лікування. Клінічна ендокринологія та ендокринна хірургія. 2016. №1 (53). C.60-71 https://doi.org/10.24026/18181384.1(53).2016.75839

9. Радченко Е.М., Королюк О.Я. Особливості перебігу та лікування ішемічної хвороби серця у хворих 3 порушеннями метаболізму глюкози та цукровим діабетом. Международный эндокринологический журнал. 2015 № 6(70). С. 1116.

10. Tušek-Bunc K., Petek D. Comorbidities and characteristics of coronary heart disease patients: their impact on health-related quality of life. Health and Quality of Life Outcomes. 2016. 14. P. 159 https://doi.org/10.1186/s12955-016-0560-1.

11. Хронічні неінфекційні захворювання: акцент на мультиморбідні патологічні стани та кардіоваскулярний ризик / Несен А.О. та ін. Украйнський терапевтичний журнал. 2019. № 1. С. 25-32. https://doi.org/10.30978/UTJ2019-1-25.

4. Knuuti, J., Wijns, W., Saraste, A., Capodanno, D., Barbato, E., Funck-Brentano, C., Prescott, E., Storey, R. F., Deaton, C., Cuisset, T., Agewall, S., Dickstein, K., Edvardsen, T., Escaned, J., Gersh, B. J., Svitil, P., Gilard, M., Hasdai, D., Hatala, R., Mahfoud, F., ... ESC Scientific Document Group (2020). 2019 ESC Guidelines for the diagnosis and management of chronic coronary syndromes. European heart journal, 41(3), 407-477. https://doi.org/10.1093/eurhearti/ehz425

5. Moroz, G. Z., Tkachuk, I.M, Yepishev, Yu.P., Mikhrina, M. I., Kravets, A. V., Zakharchuk, L. M. (2018) Tiutiunokurinnia u viiskovosluzhbovtsiv: suchasnyi stan problemy ta hotovnist do zminy nezdorovoi povedinky. Military Medicine of Ukraine, $18,1,71-76$

6. Boichak, M.P., Osodlo, H.V. (2020) Terapevtychni aspekty viiny na Skhodi Ukrainy: monohrafiia K. 320.

7. Moroz, Galina Z., Hidzynska, Irina M., Kravchenko, Anatoly M., Lasytsia, Tatyana S., Dzizinska, Olena O. 
(2020). Comorbidity in patients with chronic coronary syndromes: prevalence and assessment. Wiadomości Lekarskie, tom LXXIII, nr 3, 462-465. https://doi.org/10.36740/WLek202003110.

8. Tkach, S.M., Cheverda, T.L. (2016) Nealkoholna zhyrova khvoroba pechinky: poshyrenist, pryrodnyi perebih, suchasni pidkhody do diahnostyky ta likuvannia. Clinical endocrinology and endocrine surgery, 1 (53), 60-71. https://doi.org/10.24026/1818-1384.1(53).2016.75839.

9. Radchenko, E.M., Koroliuk, O.Ia. (2015) Osoblyvosti perebihu ta likuvannia ishemichnoi khvoroby sertsia $\mathrm{u}$ khvorykh $\mathrm{z}$ porushenniamy metabolizmu hliukozy ta tsukrovym diabetom. International Journal of Endocrinology, 6(70), 11-16.

10. Tušek-Bunc, K., Petek, D. (2016) Comorbidities and characteristics of coronary heart disease patients: their impact on health-related quality of life. Health and Quality of Life Outcomes, 14, 159. https://doi.org/10.1186/s12955-016-0560-1.

11. Nesen, A.O., Chernyshov, V.A., Shkapo, V.L., Valentynova, I.A. (2019) Khronichni neinfektsiini zakhvoriuvannia: aktsent na multymorbidni patolohichni stany ta kardiovaskuliarnyi ryzyk. Ukrainian Therapeutic Journal, 1, 25-32. https://doi.org/10.30978/UT22019-1-25.

\title{
РАСПРОСТРАНЕННОСТЬ КОМОРБИДНОЙ ПАТОЛОГИИ У ВОЕННОСЛУЖАЩИХ С ИШЕМИЧЕСКОЙ БОЛЕЗНЬЮ СЕРДЦА
}

\author{
Т.В. Куц, Г.3. Мороз
}

Украинская военно-медицинская академия, г. Киев, Украина

Цель - определить распространенность коморбидной патологии у военнослужащих, больных ишемической болезнью сердца (ИБС), проходивших лечение в кардиологическом отделении Национального военно-медицинского клинического центра «Главный военный клинический госпиталь» (НВМКЦ «ГВКГ»).

Материалы и методы. Проведен анализ 100 историй болезни случайной выборки пациентов кардиологического отделения, которые были госпитализированы в НВМКЦ «ГВКГ» в 2020 году с диагнозом ИБС. Все больные были мужского пола в возрасте от 40 до 60 лет. Для исследования возрастных особенностей распространенности коморбидной патологии больные ИБС были разделены на две группы: 40-50 лет (I группа - 45 пациентов) и 51-60 лет (II группа - 55 пациентов). Статистическая обработка проводилась с использованием программы Microsoft Excel 2007 и стандартного статистического пакета STATISTICA 6,0.

Результаты. Выявлено значительную распространенность коморбидных заболеваний у больных ИБС: количество сопутствующих заболеваний было от 2 до 10. Артериальная гипертензия диагностирована у 100\% больных I и II группы. Среди других коморбидных сердечно-сосудистых заболеваний: цереброваскулярные заболевания были диагностированы у больных I группы в 15,6 \pm 5,4\% и в $10,9 \pm 4,2 \%$ II группы (p>0,05) атеросклеротическое поражение артерий нижних конечностей - в 51,1 \pm 7,5\% и в 58,1 $\pm 6,7 \%$, соответственно ( $>>0,05)$. Наиболее распространенными коморбидными заболеваниями органов пищеварения были: хронический холецистит (у 26,7 $\pm 6,6 \%$ больных I группы и у 40,0 0 6,6\% II группы, p> 0,05), неалкогольная жировая болезнь печени (у 22,2 \pm 6,2\% и у $20 \pm 5,4 \%$, соответственно, р> 0,05), хронический гастродуоденит (у 22,2 $\pm 6,2 \%$ и у 18,1 $\pm 5,2 \%$, соответственно, р> 0,05). Ожирение было диагностировано у 22,2 \pm 6,2\% больных в I группе, и у 25,5 $\pm 5,9 \%$ во II группе (p> 0,05); сахарный диабет II

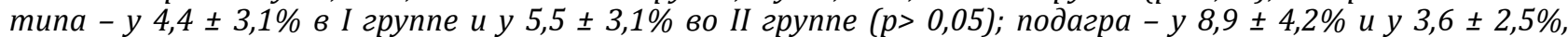
соответственно, ( $p>0,05)$; остеохондроз позвоночника - у $40 \pm 7,3 \%$ и у 29,1 $\pm 6,1 \%$, соответственно, ( $p>$ $0,05)$.

Выводы. Результаты проведенного исследования показали значительную распространенность коморбидной патологии у больных ИБС, проходивших лечение в НВМКЦ «ГВКГ», что имеет важное значение для прогноза и назначения лечения. Наиболее распространенными были артериальная гипертензия (100\%), атеросклеротическое поражение артерий нижних конечностей $(51,1 \pm 7,5 \%$ в 1 группе и 58,1 1 6,7\% во II группе, $p>0,05)$, остеохондроз позвоночника (40 \pm 7,3\% и 29,1 $\pm 6,1 \%$, соответственно, $p>0,05)$ и хронический холецистит $(26,7 \pm 6,6 \%$ и 40,0 $\pm 6,6 \%, p>0,05)$. Не определено статистически достоверных различий распространенности коморбидной патологии у больных ИБС в возрастной группе 40-50 лет и 51-60 лет.

ключевые слова: ишемическая болезнь сердца, военнослужащие, коморбидность.

\section{PREVALENCE OF COMORBID PATHOLOGY AMONG MILITARY PERSONNEL WITH CORONARY ARTERY DISEASE}

\author{
T.V. Kuts, G.Z. Moroz
}

Ukrainian Military Medical Academy, Kyiv, Ukraine

The purpose - to determine the prevalence of comorbid pathology among military personnel with coronary artery disease (CAD) who were treated in the cardiology department of the National Military Medical Clinical Center "Main Military Clinical Hospital (NMMCC "MMCH").

Materials and methods. An analysis of 100 case histories of a random sample of patients from the cardiology department who were hospitalized in the NMMCC "MMCH" in 2020 with CAD was carried out. All patients were male, aged 40 to 60 years. To study the age-specific features of the prevalence of comorbid pathology, patients with CAD 
were divided into two groups: 40-50 years (I group - 45 patients) and 51-60 years (II group - 55 patients). Statistical processing was performed using Microsoft Excel 2007 and the standard statistical package STATISTICA 6.0.

Results. A significant prevalence of comorbid diseases in patients with CAD was determined: the number of comorbidities ranged from 2 to 10. Hypertension was diagnosed in 100\% of patients of I and II groups. Among other comorbid cardiovascular diseases: cerebrovascular diseases were diagnosed in patients of I group in 15,6 $\pm 5.4 \%$ and in $10.9 \pm 4,2 \%$ of group II ( $p>0,05$ ); peripheral arterial disease - in $51,1 \pm 7,5 \%$ and $58.1 \pm 6,7 \%$, respectively ( $p>$ $0,05)$. The most common comorbid diseases of the digestive system were: chronic cholecystitis $(26,7 \pm 6,6 \%$ of patients of I group and 40,0 $\pm 6,6 \%$ of II group, p>0,05), non-alcoholic fatty liver disease $22,2 \pm 6,2 \%$ and 20,0 $\pm 5,4 \%$, respectively, $p>0,05)$, chronic gastroduodenitis $(22,2 \pm 6,2 \%$ and $18,1 \pm 5,2 \%$, respectively), $p>0,05)$. Obesity was detected in $22,2 \pm 6,2 \%$ of patients of I group, and in $25,5 \pm 5,9 \%$ of II group ( $p>0,05)$; type 2 diabetes mellitus - 4,4 $\pm 3,1 \%$ of patients of I group, and in $5,5 \pm 3,1 \%$ of patients of II group ( $p>0,05$ ); gout $-8,9 \pm 4,2 \%$ and $3,6 \pm 2,5 \%$, respectively; $(p>0,05)$, osteochondrosis $-40,0 \pm 7,3 \%$ and $29,1 \pm 6,1 \%$, respectively $(p>0,05)$.

Conclusions. The results of the study showed a significant prevalence of comorbid pathology among the patients with CAD who were treated at NMMCC "MMCH", which is important for the prognosis and treatment. The most common were hypertension (100\%), peripheral arterial disease $(51,1 \pm 7,5 \%$ in group I and $58,1 \pm 6,7 \%$ in group II, $p>0,05)$; osteochondrosis ( $40 \pm 7,3 \%$ and $29,1 \pm 6.1 \%$, respectively, $p>0,05)$ and chronic cholecystitis $(26,7 \pm 6,6 \%$ and $40,0 \pm 6,6 \%, p>0,05)$. There were no statically significant differences in the prevalence of comorbid pathology among the patients with CAD of the age group of 40-50 years and 51-60 years.

Key words: coronary artery disease, military personnel, comorbidity.

Конфлікт інтересів: відсутній.

Conflicts of interest: authors have no conflict of interest to daclare.

\section{Відомості про авторів:}

Куц Т.В., А,C,D,E,F - підполковник медичної служби, кандидат медичних наук, доцент, заступник начальника кафедри військової загальної практики-сімейної медицини Української військово-медичної академії, м. Київ, Україна

Мороз Г.3., А,B,C,D,E,F - доктор медичних наук, професор, професор кафедри військової загальної практики-сімейної медицини Української військово-медичної академії, м. Київ, Україна

A - концепція та дизайн дослідження; В - збір даних; $C$ - аналіз та інтерпретація даних;

$D$ - написання статmi; $E$ - редагування статmі; F- остаточне затвердження статті.

\section{Сведения об авторах:}

Куц Т.В., - подполковник медицинской службы, кандидат медицинских наук, доцент, заместитель начальника кафедры военной общей практики- семейной медицины Украинской военно-медицинской академии, г. Киев, Украина.

Мороз Г. 3., - доктор медицинских наук, профессор, профессор кафедры военной общей практикисемейной медицины Украинской военно-медицинской академии, г. Киев, Украина.

\section{Information about authors:}

Kuts T.V., A,C,D,E,F - LTC, MS, PHD, Associate Professor,, Deputy Head of department of Military General Practice and Family Medicine of the Ukrainian Military Medical Academy, Kyiv, Ukraine.

E-mail: taraskuts@gmail.com, https://orcid.org/0000-0001-7619-3679

Moroz G.Z., A,B,C,D,E,F - MD, professor, Professor of the department of Military General Practice and Family Medicine of the Ukrainian Military Medical Academy, Kyiv, Ukraine.

E-mail: moroz galina@i.ua, https://orcid.org/0000-0003-4329-7193

$A$ - research concept and design; $B$ - collection and/or assembly of data; $C$-data analysis and interpretation;

$D$ - writing the article; $E$ - critical revision of the article; $F$ - final approval of the article.

Адреса для листування: вул. Московська, 45/1, буд. 33, м. Київ 01015 